\title{
New adherent foraminiferans from the Lower Cretaceous (Aptian) of south-central England
}

\author{
MARK A. WILSON \\ Department of Geology, The College of Wooster, Wooster, Ohio 44691 USA
}

\begin{abstract}
Three new species and one new genus of adherent foraminiferans have been found within bivalve borings in cobbles from the Faringdon Sponge-gravel (Upper Aptian) of south-central England. The new genus and species, Lapillincola faringdonensis is a uniserial textulariine with an initial planispiral coil and a multiple aperture. Lapillincola gen. nov. is a remarkable homeomorph of Arenonina Barnard, which was originally described as an agglutinated form. Arenonina is shown here to actually be calcareous and perforate, and thus a junior synonym of Rectocibicides Cushman \& Ponton. Acruliammina parvispira sp. nov, is another uniserial textulariine with an initial coil. Bullopora ramosa sp. nov. is an adherent polymorphinid with a branching, irregular series of adherent chambers. These foraminiferans may have used the bivalve borings as spatial refuges from the abrasive, high energy environment of the Sponge-gravel.
\end{abstract}

\section{INTRODUCTION}

An unusual adherent foraminiferan fauna was found inside bivalve borings in calcareous claystone cobbles from the top $3 \mathrm{~m}$ of the Lower Cretaceous Faringdon Sponge-gravel, Faringdon, Oxfordshire, England. One new genus and three new species are described from this collection. The genus Arenonina Barnard (1958) is morphologically similar to the new genus Lapillincola, but re-examination of the type specimen of Arenonina has shown it to be calcareous perforate and not agglutinated as originally described. Arenonina is redescribed here as a junior synonym of Rectocibicides Cushman \& Ponton (1932) and a remarkable homeomorph of Lapillincola gen. nov.

\section{STRATIGRAPHY AND LOCATION}

The adherent foraminiferans were collected from the "Red gravel" (Meyer, 1864) of the Faringdon Spongegravel, $5.5-8.5 \mathrm{~m}$ above the disconformable contact with Oxfordian limestones of the Corallian Group, exposed in the Wicklesham gravel pit at the southeast edge of Faringdon, Oxfordshire (nat. grid ref. SU 293943; lat. $51^{\circ} 41^{\prime} 20^{\prime \prime} \mathrm{N}$, long. $1^{\circ} 34^{\prime} 45^{\prime \prime} \mathrm{W}$; Fig. 1). This gravel has been placed within the Parahoplites nutfieldensis Zone of the Upper Aptian (see Casey, 1961 for the detailed stratigraphy).

\section{MODE OF OCCURRENCE}

The foraminiferans are found encrusting the interiors of flask-shaped borings of the ichnogenus Gastrochaenolites Leymarie, 1842. These borings, ranging in size from $2-20 \mathrm{~mm}$ at widest diameter and $4-40 \mathrm{~mm}$ at greatest depth, are abundant in rounded calcareous claystone cobbles. One cobble contained the ammonite Prorasenia bowerbanki (kindly identified by $\mathrm{H}$. G. Owen) within its matrix, indicating that some of the cobbles, at least, were originally derived from the lower Kimmeridge Clay or the Upper Oxfordian (Upper Jurassic). These cobbles were rolled periodically, as demonstrated by their rounding and the distribution of borings and encrusters on all outside surfaces.

Approximately 40 additional encrusting and nestling species are also found in the Faringdon Gastrochaenolites borings. They include bryozoans, serpulids, brachiopods, bivalves and sponges. This fauna is described separately (Wilson, 1986).

The following suprageneric classification is based on that outlined by Loeblich \& Tappan (1984).

\section{SYSTEMATIC DESCRIPTIONS}

Order Foraminiferida Eichwald, 1830

Suborder Rotaliina Delage \& Hérouard, 1896

Superfamily Planorbulinacea Schwager, 1877

Family Cibicididae Cushman, 1927

Subfamily Stichocibicidinae Saidova, 1981

Genus Rectocibicides Cushman \& Ponton, 1932

Rectocibicides cretacea (Barnard, 1958)

(P1. 1, figs. 1-3)

1958 Arenonina cretacea Barnard: 119, pl. 22, fig. 1 (non fig. 2)

Emended diagnosis. Test completely attached, consisting of an initial trochospiral coil with shallow indistinct sutures, followed by a uniserial portion in which the 


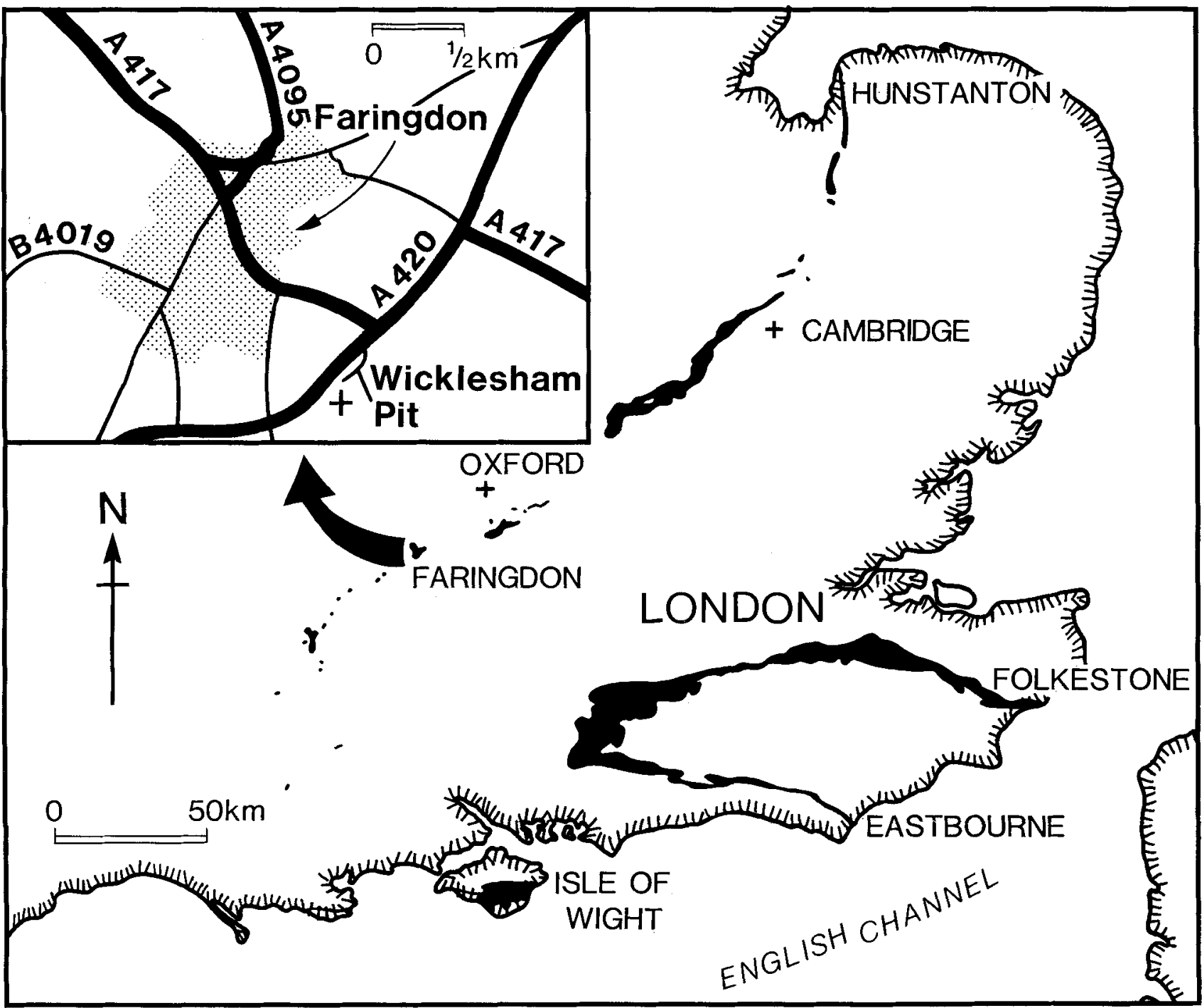

Fig. 1. Location of the Wicklesham Pit, Faringdon, where the foraminifera-bearing cobbles were collected. The solid pattern is the outcrop of the Lower Greensand (of which the Faringdon sponge-gravel is a part) in southeastern England (after Casey, 1961).

chambers are rectangular to arcuate with generally parallel septa; aperture is a row of pores extending along the length of the apertural face; each apertural pore is surrounded by a slight lip; wall calcareous and coarsely perforate.

Holotype. British Museum (Natural History) no. P 43656 (P1. 1, figs. 1-3).

Material. One specimen (the holotype).

Locality and horizon. "Upper Chalk, Zone of Micraster coranguinum, Northfleet, Kent" (Barnard, 1958, p. 119).
Description. See Barnard (1958, p. 118) for a full description of the species, noting that the wall is now know to be calcareous and perforate and not arenaceous (see below). The drawing of Arenonina cretacea accompanying the original description (Barnard, 1958, text-fig. 1) is also inaccurate. The broken portion of the last-formed chamber is drawn as a large apertural pore, and where the drawing shows 10 undamaged apertural pores there are actually 17. Barnard's (1958, text-fig. 1) drawing also shows deep sutures on the initial coil, which are not visible on the 
type specimen. A photograph of the $A$. cretacea paratype (Barnard, 1958, Pl. 22, fig. 2) shows what may be deeper sutures on the initial coil. This specimen was apparently never deposited in a museum collection, so it was unavailable for study. The photograph of the paratype is poor; because it shows none of the characteristic features of the genus, such as spreading chambers or a multiple aperture, it may represent a separate form. The drawing of $A$. cretacea produced by Barnard (1958, text-fig. 1) was reproduced in the Treatise (Loeblich \& Tappan, 1964, fig. 160) as the illustration of Arenonina.

Remarks. Barnard (1958, p. 118) erected the genus Arenonina to separate an undescribed Upper Cretaceous foraminiferan from Bdelloidina, to which it had a "superficial external resemblance". He did not place Arenonina in a family, simply listing it as one of a group of "forms with agglutinated tests" (Barnard, 1958, p. 116). Re-examination of the holotype of $A$. cretacea with the aid of a scanning electron microscope showed that the test is calcareous, coarsely perforate and not "arenaceous". Because it also possesses a trochospiral initial coil and a multiple aperture on the terminal face, Arenonina is a junior synonym of Rectocibicides Cushman \& Ponton (1932), previously described from the Miocene of Florida. $R$. cretacea differs from $R$. miocenicus Cushman \& Ponton (1932) by the very shallow sutures on the initial coil, the more parallel septa in the uniserial portion of the test, and the reduced apertural lips.

Rectocibicides cretacea is not found in the Faringdon Sponge-gravels, but it is an impressive calcareous homeomorph of the agglutinated Lapillincola faringdonensis gen. et sp. nov. described below (Pl. 1, fig. 4). Both tests possess an initial coil with very shallow sutures followed by a uniserial portion with spreading chambers and a multiple aperture consisting of a row of pores.

\section{Suborder Textulariina Delage \& Hérouard, 1896 \\ Superfamily Lituolacea de Blainville, 1827 Family Placopsilinidae Rhumbler, 1913 Genus Lapillincola gen. nov.}

Type species. Lapillincola faringdonensis sp. nov. Derivation of name. From the Latin, lapillus (little stone) and incola (dweller).

Diagnosis. Test completely attached, consisting of a planispiral initial coil with shallow, nearly absent sutures, followed by a uniserial portion in which the chambers are rectangular to arcuate with generally parallel septa; aperture is a row of pores extending along the length of the apertural face; wall is agglutinated with simple (not labyrinthic) internal structure.
Remarks. Lapillincola is distinguished from Rectocibicides Cushman \& Ponton (1932) by the agglutinated wall structure; from Placopsilina by the multiple apertures, and from Acruliammina by the absence of an erect distal portion or a cribrate aperture.

Lapillincola faringdonensis sp. nov. (Pl. 1, fig. 4; Pl. 2, figs. 1 and 2)

Derivation of the name. From the type locality. Diagnosis. As for genus.

Holotype. British Museum (Natural History) no. P 51736.

Material, 27 specimens.

Locality and horizon. Upper Aptian, Parahoplites nutfieldensis Zone, "Red gravel" of the Faringdon Sponge-gravel, $5.5-8.5 \mathrm{~m}$ above the disconformable contact with Oxfordian limestones of the Corallian Group, Wicklesham gravel pit, southeast Faringdon, Oxfordshire (nat. grid ref. SU 293943; Fig. 1).

Description. Test entirely adherent and agglutinated, consisting of coarse, angular grains in a calcareous matrix. Interior walls are simple and not labyrinthic. The initial planispiral coil is one or two whorls, with five to ten chambers in each whorl; sutures are very shallow to indistinct within each whorl. Occasionally an elliptical scar is present near the centre of the coil, possibly indicating the presence of a bulbous proloculus. The uniserial portion of the test contains 10-15 chambers, each delimited by distinct, usually arcuate, sutures. The uniserial chambers increased in height slowly with growth, but chamber width increased much faster, producing a flabellate or spatulate test. The aperture is known only from the uniserial chambers; it is a single row of pores extending across the face of the last-formed chamber parallel to the attachment surface. These pores, numbering in a single aperture from five to eight, are simple openings without lips or associated crenulations. The apertural pore row is usually midway between the attachment surface and the centre of the apertural face.

Dimensions. Holotype length $=5.09 \mathrm{~mm}$.; diameter of initial coil $=0.81 \mathrm{~mm}$.; width of last-formed uniserial chamber $=1.05 \mathrm{~mm}$.

\section{Genus Acruliammina Loeblich \& Tappan, 1946 Acruliammina parvispira sp. nov.}

(PI. 2, figs. 3-6)

Derivation of name. From the Latin, parvus (small) and spira (coil).

Diagnosis. Acruliammina with a small initial planispiral coil (diameter less than half the width of the mature apertural face). 
Holotype. British Museum (Natural History) no. P 51737.

Material. 7 specimens.

Locality and horizon. As above.

Description. Test adherent for all or most of its length, agglutinated, walls consisting of fine to coarse grains in a calcareous matrix. Interior walls are simple. The initial planispiral coil is one or two whorls with 7-10 chambers per whorl; sutures are moderately deep and distinct. A bulbous proloculus is present in some specimens. The initial coil is followed by an irregularly winding series of chambers with distinct sutures; chamber length and width increase in approximately equal proportion. The distal portion of the test may have grown free from its attachment after 10 to 20 adherent uniserial chambers were formed. The aperture consists of two pores on the distal face of the early uniserial chambers. In more mature forms the apertural face has three or four pores arranged in a semi-circle or complete circlet.

Dimensions. Holotype length $=4.21 \mathrm{~mm}$; width of initial coil $=0.33 \mathrm{~mm}$; width of apertural face $=$ $0.87 \mathrm{~mm}$.

Remarks. A. parvispira has a much smaller initial coil than $A$. longa (Tappan, 1940) or $A$. serpula (Tappan, 1943) of the North American midwestern Cretaceous. $A$. longa has a coil almost twice as wide as the mature apertural face, whereas the diameter of the A. parvispira coil is usually less than half the width of the mature apertural face.

Suborder Lagenina Delage \& Hérouard, 1896

Superfamily Nodosariacea Ehrenberg, 1838

Family Polymorphinidae d'Orbigny, 1839

Subfamily Webbinellinae Rhumbler, 1904

Genus Bullopora Quenstedt, 1857

Bullopora ramosa sp. nov.

(Pl. 2, figs. 7 and 8)

Derivation of name.' From the Latin, ramosus (branching).

Diagnosis. Bullopora with irregular tubular chambers, a dichotomously branching test, and a wall ornamentation of tubercles.
Holotype. British Museum (Natural History) no. P 51735.

Material. 17 specimens.

Locality and horizon. As above.

Description. Test entirely adherent; wall perforate and formed of radiate, fibrous calcite. Basal attachment wall thick. Chambers irregular and tubular, usually swollen and connected by stolons. Outer walls ornamented with fine tubercles. Uniserial series of chambers with irregular dichotomous branching points. Proloculus enveloped by the second chamber, so its form is unknown. Apertures terminal and simple.

Dimensions. Holotype: length of entire test $=2.10 \mathrm{~mm}$; width of largest chamber $=0.40 \mathrm{~mm}$.

Remarks. B. ramosa is the only species of Bullopora with dichotomous branching. B. rostrata Quenstedt (1857) and B. laevis (Sollas, 1877) develop irregular tubular chambers (as described by Adams, 1962), and $B$. tuberculata (Sollas, 1877) has a similar tuberculated exterior.

\section{DISCUSSION}

These Faringdon foraminiferans are found in an unusual environment: within the vacated borings of bivalves on loose calcareous claystone cobbles. Most adherent foraminiferans are described from encrusted shells, but a few taxa have been previously noted on hardgrounds (Voigt, 1970; Kaever, 1974; Palmer, 1982). Fossil foraminiferans have been described from within borings, most notably from the Cretaceous of the Netherlands (Hofker, 1965) and the British Jurassic (Hitchings, 1980). Indeterminate calcareous foraminiferans were noted on a loose (or "mobile") hardground of Upper Carboniferous intraclasts by West \& Palmer (1982), and foraminiferans have long been described encrusting Jurassic and Cretaceous phosphatic nodules in Europe (Chapman, 1892; Kennedy \& Garrison, 1975). This paper, however, records the first occurrence of foraminiferans within borings in a "mobile hardground" (Wilson, 1985) of loose cobbles.

The Faringdon Sponge-gravel was deposited in narrow tidal channels during an Early Cretaceous transgression (Bridges, 1982). The gravel, derived from a variety of pre-Cretaceous units, was continually reworked in its upper layers (Krantz, 1972). Adherent

\section{Explanation of Plate 1}

Figs. 1-3. Rectocibicides cretacea (Barnard), holotype BM(NH) no. P 43656, Upper Chalk, Northfleet, Kent: figs. la, b, stereo-pair $(\times 35)$; fig. 2 , stereo-pair showing the multiple aperture $(\times 37)$; fig. 3 , magnified view of the apertural pores $(\times 200)$.

Fig. 4. Lapillincola faringdonensis gen. et sp. nov., holotype from the Faringdon Sponge-gravel, Oxfordshire; $\mathrm{BM}(\mathrm{NH})$ no. P $51736(\times 11)$. 
New Lower Cretaceous adherent foraminiferans
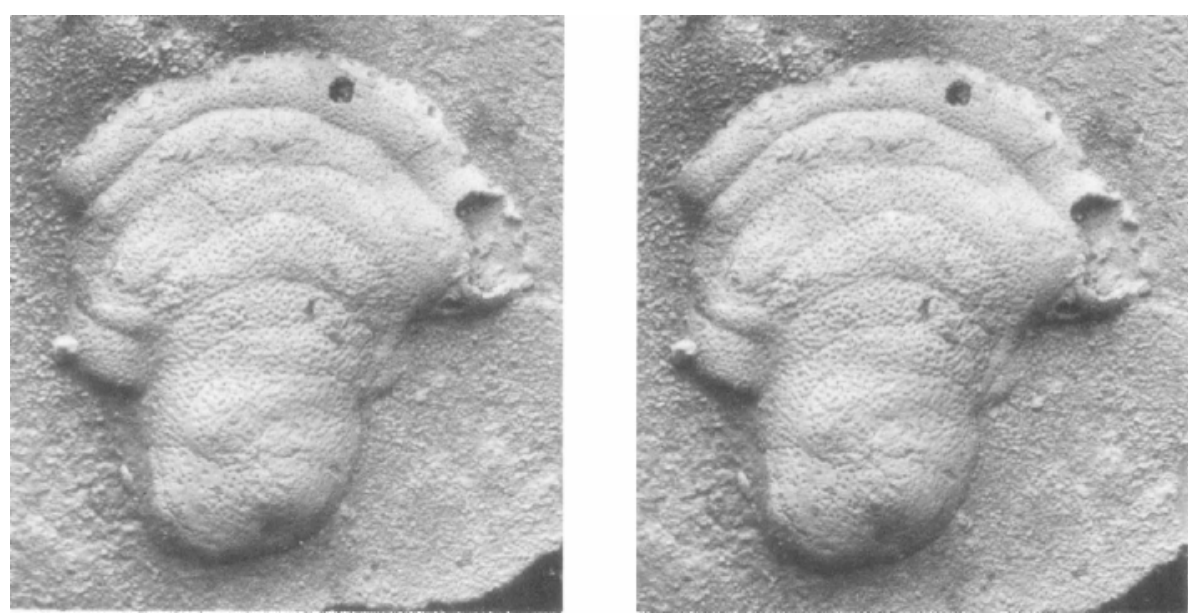

la

1b
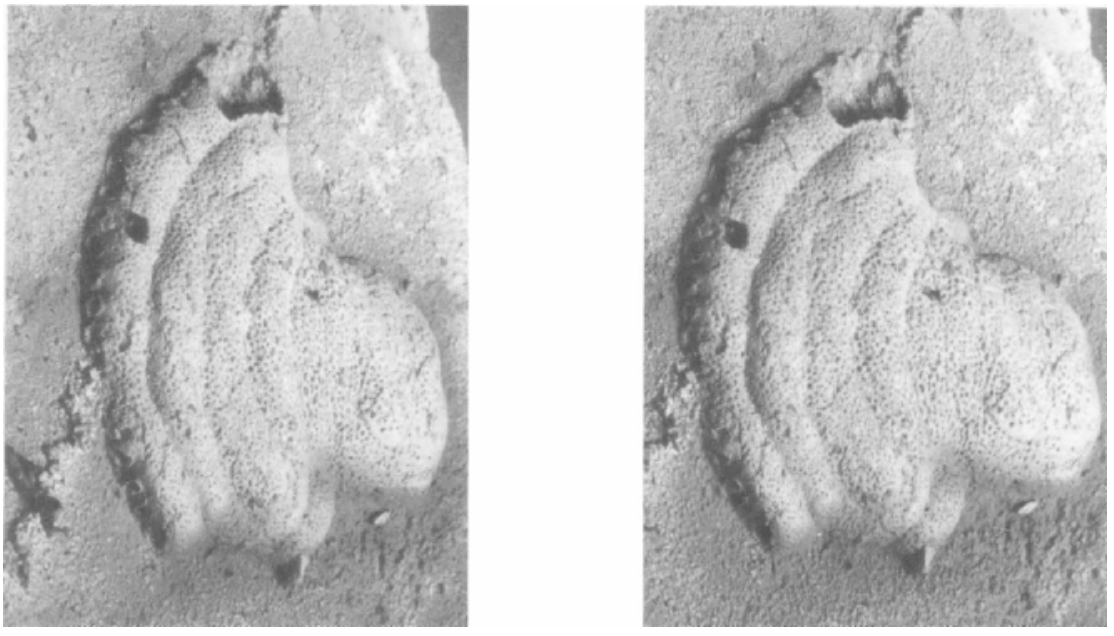

$2 a$

$2 b$
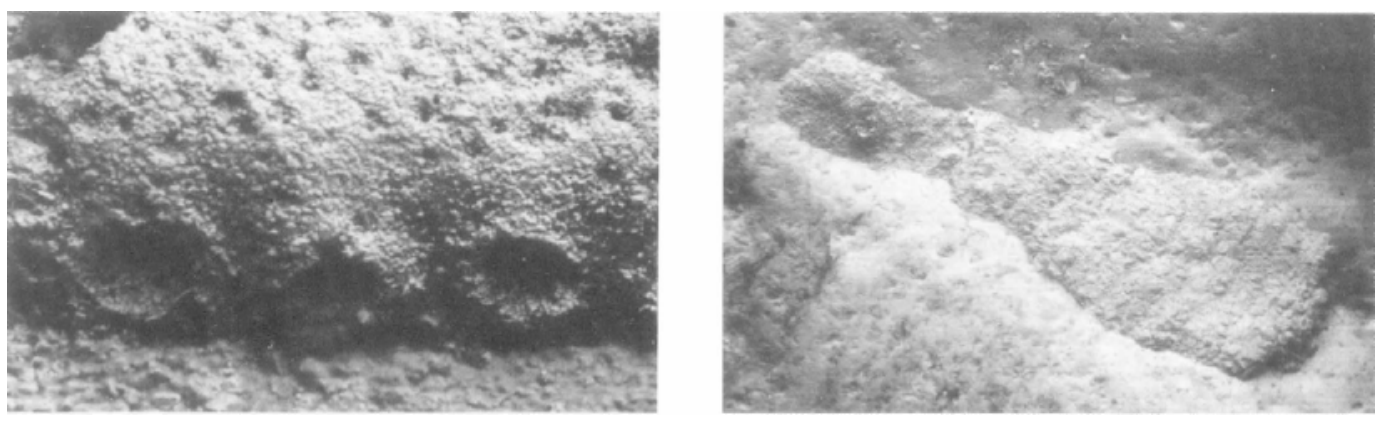
foraminiferans, with their relatively fragile shells, would have had difficulty surviving on the external surfaces of shells or cobbles under these abrasive conditions. The borings, though, provided a spatial refuge, protecting them from the physical dangers in the loose gravel and from most, if not all, epifaunal predators. Many of the borings intersected other cavities, so there was usually the possibility of flowthrough water currents, even within the centres of the cobbles.

\section{ACKNOWLEDGEMENTS}

J. E. Whittaker and F. T. Banner were helpful with their advice and criticism. I also thank P. D. Taylor, W. S. McKerrow, W. J. Kennedy, H. P. Powell, G. M. Wilson, R. Goldring and T. J. Palmer. C. Fagg, C. Grainger, J. Bishop and R. McAvoy provided excellent technical assistance. This project was completed during a research leave in the Department of Earth Sciences at the University of Oxford. I am grateful to both Oxford and The College of Wooster for their generosity.

Manuscript received October 1985

Revised manuscript accepted November 1985

\section{REFERENCES}

Adams, C. G. 1962. Calcareous adherent Foraminifera from the British Jurassic and Cretaceous and the French Eocene. Palaeontology, London, 5, 149-170, pls. 21-24.

Barnard, T. 1958. Some Mesozoic adherent foraminifera. Palaeontology, London, 1, 116-124, pls. 22-25, 2 figs.

Bridges, P. H. 1982. Ancient offshore tidal deposits. In Stride, A. H. (Ed.), Offshore tidal sands, Chapman and Hall, London, 172-192, 11 figs.

Casey, R. 1961. The stratigraphical palaeontology of the Lower Greensand. Palaeontology, London, 3, 487-621, pls. 77-84, 10 figs.

Chapman, F. 1892. Some new forms of hyaline foraminifera from the Gault. Geol. Mag., London, 9, 52-54, pl. 11.

Cushman, J. A. \& Ponton, G. M. 1932. Some interesting new Foraminifera from the Miocene of Florida. Cushman Lab. Foram. Research Contrib., 8, 1-4, pl. 1.

Hitchings, V. H. 1980. Tentilenticulina latens, n. gen., n. sp., a new foraminifer from the Corallian (Jurassic), Great Britain. Micropaleontology, New York, 26, 216-221, pl. 1, 3 figs.

Hofker, J. 1955. The Foraminifera of the Vincentown Formation. Rep. McLean Foram. Lab., Alexandria, 2, 1-21, pls. 1-6.

Hofker, J. 1965. Foraminifera from the Cretaceous of South Limburg, Netherlands. LXXVII. Arenaceous Foraminifera attached on the walls of the holes in the hard grounds of the lower $\mathrm{Md}$ in the quarry Curfs: Coscinophragma cribrosum (Reuss); Placopsilina cenomana d'Orbigny; Bdelloidina vincentownensis Hofker. Natuurhist. Maandbl., Maastricht, 54, 29-32, 10 figs.

Kaever, M. 1974. Saandschalige Foraminiferen und andere Epizoen auf einem erratischen Geröll im Turon (Soester Grünsand) des südöstlichen Münsterlandes (Westfalen). N. Jb. Geol. Palaont. Abh., Stuttgart, 146, 179-194, 3 figs.

Kennedy, W. J. \& Garrison, R. E. 1975. Morphology and genesis of nodular phosphates in the Cenomanian Glauconitic Marl of south-east England. Lethaia, Oslo, 8, 339-360, 12 figs.

\section{Explanation of Plate 2}

Fig. 1. Lapillincola faringdonensis gen. et sp. nov., view of the multiple aperture; BM(NH) no. P $51736(\times 26)$.

Fig. 2. L. faringdonensis magnified view of a damaged initial coil showing possible proloculus scar; BM(NH) no. P $51736(\times 38)$.

Fig. 3. Acruliammina parvispira sp. nov., holotype from the Faringdon Sponge-gravel, Oxfordshire; BM(NH) no. P $51737(\times 12)$.

Fig. 4. A. parvispira apertural face of a juvenile specimen; $\mathrm{BM}(\mathrm{NH})$ no. P $51738(\times 22)$.

Fig. 5. A. parvispira magnified view of the initial coil and bulbous proloculus; $\mathrm{BM}(\mathrm{NH})$ no. P $51737(\times 50)$.

Fig. 6. A. parvispira entire test, showing a broken cribrate aperture; BM(NH) no. P $51739(\times 9)$.

Fig. 7. Bullopora ramosa sp. nov. holotype from the Faringdon Sponge-gravel, Oxfordshire; BM(NH) no. P 51735 $(\times 23)$.

Fig. 8. B. ramosa magnified view of a broken cross-section of the test wall showing the fibrous calcite composition; $\mathrm{BM}(\mathrm{NH})$ no. $\mathrm{P} 51734(\times 90)$. 

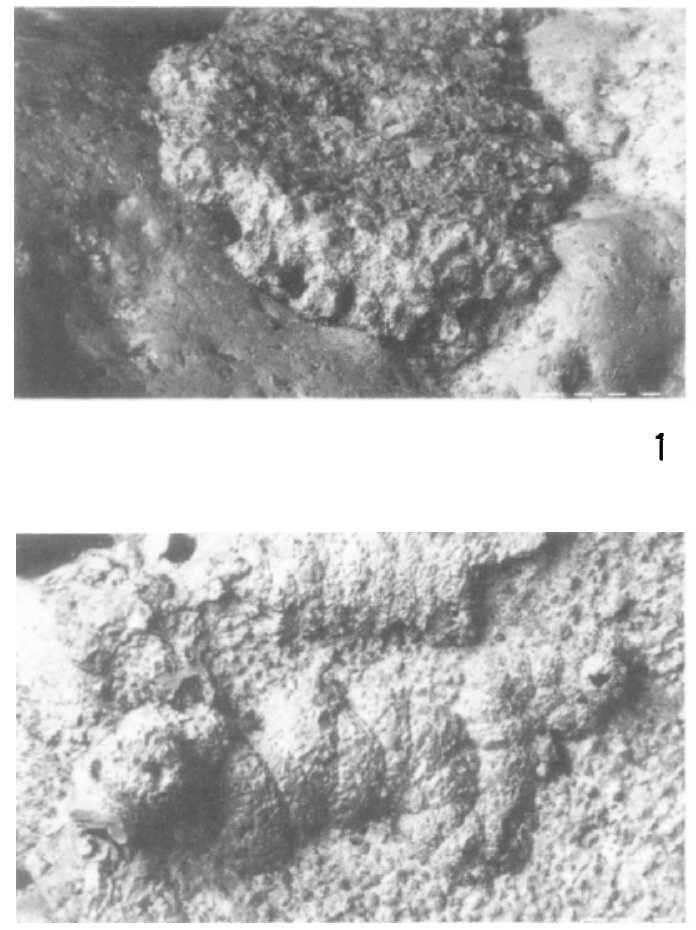

3

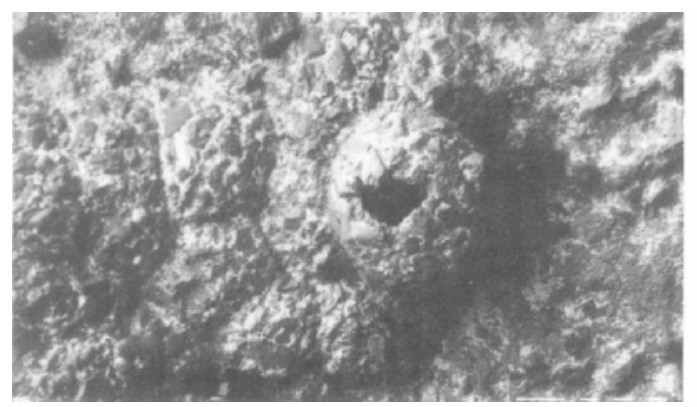

5

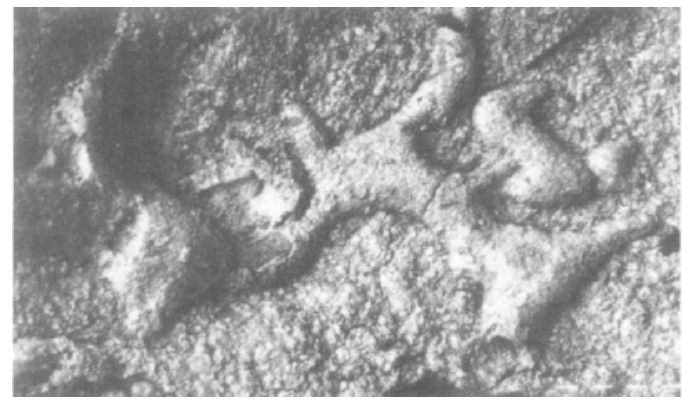

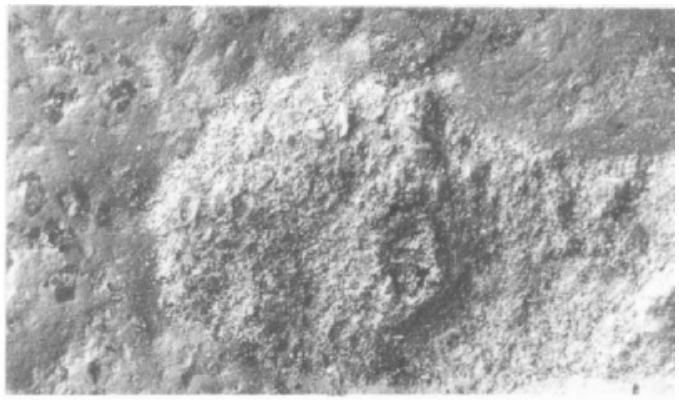

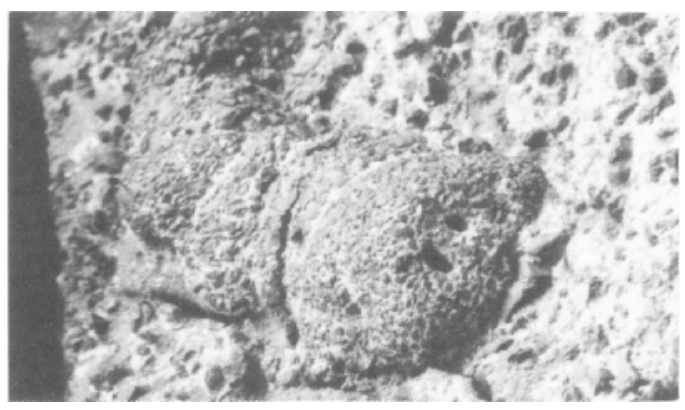

4

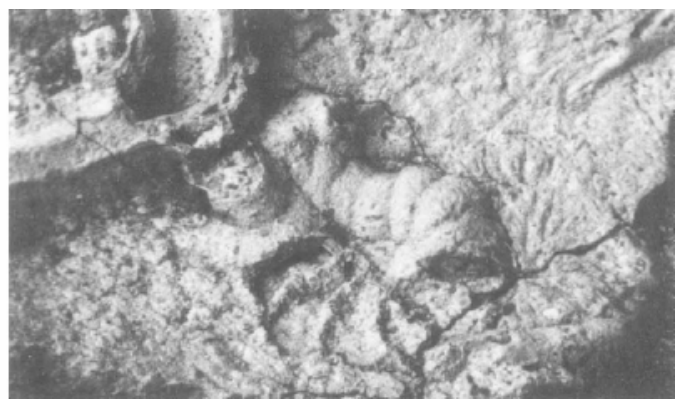

6

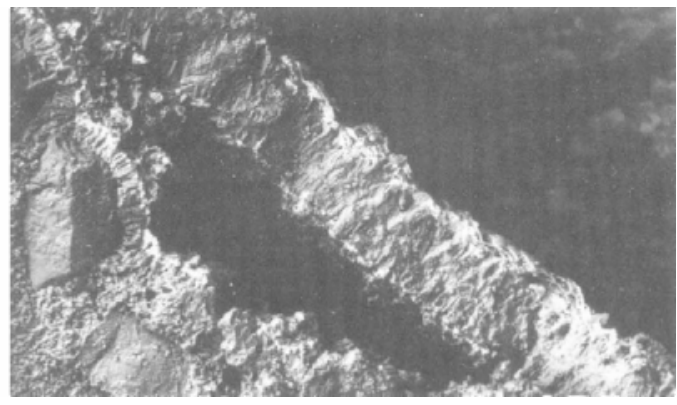

8 
Krantz, R. 1972. Die Sponge-Gravels von Faringdon (England). N. Jb. Geol. Palaont. Abh., Stuttgart, 140, 207-231, 11 figs.

Loeblich, A. R., Jr. \& Tappan, H. 1946. New Washita Foraminifera. J. Paleont., Tulsa, 20, 238-258, pls. 35-37, 4 figs.

Loeblich, A. R., Jr. \& Tappan, H. 1964. Sarcodina chiefly "Thecamoebians" and Foraminiferida. In Moore, R. C. (Ed.), Treatise on Invertebrate Paleontology, Pt. C, Protista, 2, xxxi +900 pp., 653 figs. Univ. Kansas Press.

Loeblich, A. R., Jr. \& Tappan, H. 1984. Suprageneric classification of the Foraminiferida (Protozoa). Micropaleontology, New York, 30, 1-70.

Meyer, C. J. A. 1864. Three days at Farringdon. Geologist, London, 7, 5-11.

Palmer, T. J. 1982. Cambrian to Cretaceous changes in hardground communities. Lethaia, Oslo, 15, 309-323, 9 figs.

Quenstedt, F. 1857. Der Jura. H. Laupp, 577-824, pls. 73-100. Tübingen, Germany.

Sollas, W. J. 1877. On the perforate character of the genus Webbina with a notice of 2 new species, $W$. laevis and $W$. tuberculata from the Cambridge Greensand. Geol. Mag., London, 4, 102-105, pl. 6.

Tappan, H. 1940. Foraminifera from the Grayson Formation of northern Texas. J. Paleont., Tulsa, 14, 93-126, pls. 14-19.

Tappan, H. 1943. Foraminifera from the Duck Creek Formation of Oklahoma and Texas. J. Paleont., Tulsa, 17, 476-517, pls. 77-83.

Voigt, E. 1970. Foraminiferen und (?) Phoronidea als Kommensalen auf den Hartgründen der Maastrichter Tuffkreide. Palaont. Z., Stuttgart, 44, 86-92, pls. 10-11.

West, R. R. \& Palmer, T. J. 1983. Subaerially formed "hardground" in the Upper Carboniferous of North America (abs.). First Intl. Congress on Paleoecology, Lyon, France, abstract no. 155.

Wilson, M. A. 1985. Disturbance and ecologic succession in an Upper Ordovician cobble-dwelling hardground community. Science, Washington, 228, 575-577.

Wilson, M. A. 1986. Coelobites and spatial refuges in a Lower Cretaceous cobble-dwelling hardground fauna. Palaeontology, London, 29, 691-703, pl. 53. 